\title{
Primary health care: an evolutionary agenda
}

"In no other developed country has the primary care physician achieved such a central role." How many family doctors in practice in the early 1960s, when the future of general practice looked bleak, would have dared to forecast such a confident statement about their craft 25 years on? The quotation, from some optimistic introductory paragraphs on general medical services in the government's document Primary Health Care: An Agenda for Discussion shows that the government appreciates the value of general practice in Britain's health service. ${ }^{1}$ Without that acknowledgment any suggestions for reforming primary health care would have fallen on unreceptive professional ears.

The government's long awaited proposals have worthy objectives: to make the services more responsive to the consumer, to raise standards, to promote health and prevent illness, to widen patients' choices, to improve value for money, and to clarify priorities for primary care within the National Health Service. Doctors are unlikely to cavil at these aims. They will, however, want to examine the proposed means of achieving them, so they will welcome the eight months allowed for discussion. This is an unusually long consultative period for a government with a reputation for forcing the pace of change in the NHS. This time ministers will be canvassing a wide range of consumer opinions as well as the customary professional organisations. Doubtless this and the not too distant general election dictated a timetable that makes major changes unlikely until a new parliament is elected. Meanwhile the government can claim to be doing something-without unduly provoking powerful groups in the NHS at a politically sensitive time.

The "agenda for discussion," which, with only low key references to private practice, is a far cry from the radical free market initiative implied in the many leaks during its long gestation, covers all parts of the family practitioner services -medicine, dentistry, pharmacy, the ophthalmic servicesand all parts of the United Kingdom. It also includes nursing, for the Secretary of State for Social Services has simultaneously published Neighbourhood Nursing-A Focus for Care, ${ }^{2}$ the report of the government appointed community nursing review, because its recommendations (p 1159), most of which doctors should welcome, are relevant to primary health care and he wants to include them in the consultative process. Thus, Mr Fowler can reasonably claim, as he has, to be undertaking the most comprehensive review of primary health care since the NHS was launched.

In respect of general medical services, however, on which we focus here, this initiative--even if the government were to convert all of it into action-is unlikely to change general practice as profoundly as did the Family Doctor Charter negotiations. ${ }^{3}$ Those massive changes were prompted by deep and widespread professional dissatisfaction and aimed at re-establishing a viable financial base in general practice that offered incentives for better practice and rewards for work done. The reforms, which achieved their aims, were based on revolutionary professional initiatives to which the government had urgently to respond or see general practice irretrievably deteriorate.

The government's 1986 "evolutionary" agenda has a different pedigree, with several different pressures persuading ministers to act. There was the thrust of the Conservative party's ideological commitment to more competition and thus better consumer choice, a "wind of change" that the government saw no reason should not blow through the professions, too. The sharply rising cost of health care was another factor. In particular, the Treasury was worried at the openended financial consequences of a demand led family practitioner service at a time when its priority was to cut public expenditure. There may also have been concern that the complexities of general practitioners' remuneration made identifying expenses and income the province of a few experts. To contain expenditure the government has already introduced the limited list ${ }^{4}$ revised the opticians' service, and proposed a new contract for pharmacists. In 1982 the Department of Health and Social Security set up the Binder Hamlyn inquiry into controlling costs in general practice. Although that inquiry's report has never been published, leading to speculation that it may have shown how cost effective general practice already was and how difficult it would be to "cash limit" its budget, Norman Fowler conceded that it had contributed to the latest document. A pity then that it was never made public. Certainly, one report that was published, the General Medical Services Committee's General Practice: A British Success, emphasised the good bargain that Britain was getting from its family doctors.

There has been pressure, too, from other political parties with their own ideas on the direction that general practice should take. ${ }^{67}$ Another pressure came from the public. Doctors still remain high in the public's esteem, but there has been a groundswell of complaints about certain aspects of general practice. A public expecting more from medicine has been uneasy that despite most doctors working from better premises with more staff and more leisure time it sometimes takes longer than in the past to see the doctor and it is often harder to see the doctor they wanted, especially out of hours. The government's action in tightening up the rules on general practitioners' use of deputising services was one (somewhat precipitous) response to such consumer anxiety. ${ }^{8}$

Then there has been pressure from the medical profession. For several years the BMA has been wanting to negotiate changes in general practitioners' contracts, with the "second charter" one such abortive drive for change. ${ }^{9}$ Twice recently Dr Michael Wilson, chairman of the GMSC, has written to ministers listing over a dozen proposals from his committee for developing general practice that were being stalled by the Department of Health and Social Security. ${ }^{10}$ The Royal College of General Practitioners, too, has been promoting its initiative to improve the quality of general practice, ${ }^{11}$ and the government has made no secret of its use of the college's proposals in preparing its own suggestions. A wish for cost effectiveness through greater (possibly privatised) competitiveness may have launched the government on its quest to improve primary care, but a quest for quality has joined value for money. With a combination of financial incentives, consumer choice, and tougher supervision by family practitioner committees the government wants "to raise the general quality of these services nearer to that of the best."

Doctors will applaud this aim: they may jib at the means. The mixed reception in the profession to the RCGP's publication Quality in General Practice showed what a sensitive topic this is. " The profession's reservations have not, however, deterred the government from proposing that entitlement to its suggested "good practice allowance" might 
be linked to factors such as: personal availability to patients, the provision of a wide range of services including preventive activities, a good score for services such as immunisation, and attendances at postgraduate courses (which have declined sharply since they ceased to be a condition for receiving seniority allowances). These are reasonable suggestions, but Norman Fowler and his ministerial colleagues have also floated the more contentious idea of peer review for general practitioners, albeit after some pilot studies. As the document points out, training practices are already assessed -but the effectiveness of this assessment has been questioned, and a major practical obstacle would be the amount of professional time it would absorb, as well as an inevitable growth in bureaucracy and a risk of nepotism. Even so, the profession must face squarely the possibility of peer review; the public perception that some practices are not as good as they should be is too strong to brush aside.

As part of its quest for quality the government argues that the capitation fee (now about $45 \%$ of a doctor's fees and allowances) should be increased because it "may not adequately recognise the extent to which work and responsibility vary with the number of patients." Those who recall the charter negotiations will remember that the capitation system was criticised because it meant that the doctor got paid however few services he gave of whatever standard-an argument that still seems valid.

The inner cities are the one place where the quality of general practice varies most, and it is no credit to this government that it has acted so slowly on the excellent recommendations in the 1981 Acheson report on inner London. ${ }^{12}$ Five years later the government has given these recommendations another airing, but there is little sign of the necessary urgent action. Phrases such as "there is a case for providing financial incentives to ensure that practising in these areas offers equivalent attraction to working elsewhere," and "the government will explore the possibility of experiments [in differing contractual arrangements for doctors] . . . in a small number of pilot areas," do not engender confidence. They suggest a government long on fine words but short on action that requires extra money. The profession should demand immediate extra investment in the inner cities to improve medical services.

One identifiable problem in the inner cities has been the number of elderly, singlehanded doctors still in practice. The discussion document will have surprised no one in its commitment to a compulsory retirement age of 70 for general practitioners. Furthermore, the government has made no secret of its dislike of the 24 hour retirement arrangement, by which a general practitioner retires, takes his lump sum from the superannuation scheme, and rejoins his practice to draw his pension and an income-the pension unabated if he is over 65. Mr Fowler intends to end this arrangement. Doctors would be wise not to fight these two proposals-given that suitable safeguards can be negotiated-because they will attract widespread political and public support. This is not just because patients may have reservations about being treated by elderly doctors. The BMA's publicity about the difficulties of young doctors obtaining career posts do not sit comfortably with a defence of the status quo on retirement.

Some of the report's other proposals will be controversial - for example, more general practitioner participation in child health care and "health care shops" containing all professional services that could lay the foundations for
American style health maintenance organisations. Several others that are unlikely to be controversial in principlethough the details will be argued over-cover more pre- $-\frac{0}{-}$ ventive medicine, improved information on practices for patients, simplification of the complaints procedure with alp family practitioner committees adopting an initial informat procedure, and an easier method for patients to change 5 doctors. These last three tie in with the government'sp philosophy of strengthening the consumer's power. Para-s doxically, in some parts of the country the very success of the Family Doctor Charter in encouraging the growth of group. practices has reduced patients' choice because a small towns? or rural area can often sustain only one such practice. Thereo the government may find it hard to improve choice, and in $20 \overline{0}$ discussion document short on practical detail we are not toldes how this objective might be achieved.

For general practitioners any negotiations on the proposals should be made easier by the government's unequivoca 5 rejection of two suggestions floated in the Cumberlege report-namely, that general practitioners should be salaried and $\vec{\omega}$ that family practitioner committees should be incorporatedo into district health authorities. Even the Labour and Socia Democratic parties tread warily on the subject of a salariedto service for general practitioners, for it is widely recognised that, save in certain specialised circumstances, to try ton introduce that would guarantee a major medicopolitical confrontation with the General Medical Services Committee $\vec{v}$ The independence that NHS general practitioners have enjoyed since 1948 may have some drawbacks but the advantages to the public and to the Treasury greatly out ${ }_{3}$ weigh them. A better case could be made on planning and operational grounds for the integration of family practitioner committees and health authorities. But with the NHS still inge administrative confusion after its recent reorganisations anyb idea of amalgamation is unrealistic.

This agenda for discussion may disappoint radicals on the left and right-though it may contain a "hidden agenda" for activation by a future Tory government-but the House of Commons (p 1213) and the BMA have given it a cautious: welcome. $^{13}$ The government has, however, ducked the 3 question of how much the proposals would cost and it has not? even hinted that there may be problems in negotiating the changes in general practitioners' contracts that will bes needed if its aims are to be fulfilled. Political considerations s? aside, such negotiations are a major reason why it would bej unrealistic to expect these proposals to be translated into action before a general election.

1 Department of Health and Social Security. Prmary health care. An agenda for discussion. London $\mathbb{N}$

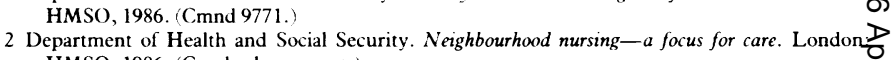
HMSO, 1986. (Cumberlege report.)

3 British Medical Association. A charter for the family doctor service. Br Med $\mathcal{f}$ 1965;i:89-9

4 Department of Health and Social Security. Health service development. Familv practitioner service $\mathrm{N}$
(supplement) Limiting the range of drugs prescribable under the NHS-arrangements for family practitioner services. London: DHSS, 1985. (HC(FP) $(85) 9$.

5 General Medical Services Committee. General practice. A British success. London: BMA, 1983. 6 Labour party. Labour putting people first. London: Labour party, 1986.

7 Social Democratic party. Primary health care. London: Social Democratic party, 1986.

8 Department of Health and Social Security. Family practitioner services. General practitione deputising services. London: DHSS, 1984. (HC(FP) (84)2.

9 General Medical Services Committee. Report of the new charter working group. London: BMA 1979 .

10 Anonymous. GMSC chairman criticises government's "indecision." Br Med f 1986;292:72.

11 Royal College of General Practitioners. Quality in general practice. London: Royal College of General Practitioners, 1985.

12 London Health Planning Consortium Study Group on Primary health Care in Inner London Report. London: DHSS, 1981. (Acheson report.)

13 Anonymous. BMA's statement. BrMed f 1986;292:1152. 